\title{
Abdelrazik: Tort Liability for Exercise of Prerogative Powers?
}

\section{Erika Chamberlain*}

\section{Introduction}

From 2003 to 2009, Mr. Abousfian Abdelrazik was effectively exiled in Sudan. A Canadian citizen, Abdelrazik had travelled to Sudan on a valid Canadian passport to visit his ailing mother. He was subsequently arrested and detained by Sudanese authorities, during which time his passport expired. In the ensuing years, he made numerous attempts to return home to Canada. These efforts were hampered by suspicions that he was a terrorist, by the resulting wariness of commercial airlines to accept him as a passenger, and by his eventual destitution. Abdelrazik was finally able to obtain an airline ticket to Toronto for April 3, 2009. But when he contacted the Minister of Foreign Affairs to obtain the emergency passport that had been assured to him, it was summarily refused.

Abdelrazik ultimately returned to Canada in June 2009, after Federal Court Justice Zinn ordered the Canadian government to issue an emergency passport and arrange for his return. ${ }^{1}$ He has since filed a statement of claim ${ }^{2}$ in the Federal Court against the Attorney General and the Minister of Foreign Affairs, alleging, inter alia, breaches of sections 6,7 and 12 of the $\mathrm{Ca}$ nadian Charter of Rights and Freedoms, ${ }^{3}$ false imprisonment, intentional infliction of mental suffering, and breach of fiduciary duty. The focus of this comment, however, is Abdelrazik's claim against the Minister of Foreign Affairs for the tort of misfeasance in a public office. Abdelrazik alleges that the minister's refusal to issue him an emergency passport in April 2009 was deliberately unlawful and made in bad faith.
The tort of misfeasance in a public office (sometimes referred to as abuse of office, abuse of power, or public misfeasance) holds some historical interest, and it was critical in a series of election-rigging cases in the eighteenth and early nineteenth centuries. ${ }^{4}$ Indeed, Lord Justice Holt's decision in Ashby v. White is perhaps the most famous application of the maxim, ubi ius, ibi remedium ("where there is a right, there is a remedy"). ${ }^{5}$ But the tort fell into disuse for most of the twentieth century, and has only been resurrected in the last 25 years. Since the turn of the millennium, the decisions of the House of Lords in Three Rivers District Council v. Governor and Company of the Bank of England (No. $3)^{6}$ and the Supreme Court of Canada in Odhavji Estate v. Woodhouse, ${ }^{7}$ which affirmed and restated the elements of the tort, have encouraged plaintiffs to plead misfeasance in a public office with greater frequency. ${ }^{8}$ It is now common for plaintiffs to plead misfeasance in their claims against public officials, alongside better-known torts like false imprisonment, malicious prosecution, or negligence. ${ }^{9}$ Misfeasance is also a promising option for plaintiffs wishing to challenge administrative actions, such as licensing or municipal planning decisions. ${ }^{10}$

However, to the author's knowledge, the claim by Abdelrazik will be the most highprofile instance of misfeasance in a public office being claimed for the exercise of a prerogative power (i.e., the refusal to issue a passport). ${ }^{11}$ Needless to say, this claim has significant implications in terms of the separation of powers. Although the days of complete discretion in the exercise of prerogative powers have long passed, and they are now undoubtedly susceptible to 
judicial review, ${ }^{12}$ there is something about the potential for consequences in tort that causes unease. To what extent should the courts be declaring, as a matter of private law, that prerogative actions of the executive branch are wrongful and give rise to a claim for damages?

Misfeasance in a public office, as the only tort that applies exclusively to public-law defendants, inherently raises questions about the appropriateness of using private law to sanction public officials. Nevertheless, most misfeasance cases involve more mundane issues of licensing, zoning, or professional discipline, where judicial review of administrative action is relatively uncontroversial. The Abdelrazik litigation, by contrast, presents an opportunity for the public/private debate to be aired in a context where the stakes are much higher. Set against the backdrop of alleged terrorism, torture, and national security risks, the Abdelrazik case will likely spawn impassioned arguments about government accountability and human rights on the one hand, and executive discretion and national security on the other. While these arguments will undoubtedly be influenced by the Supreme Court's recent decision in Canada (Prime Minister) v. Khadr, ${ }^{13}$ which was released just as this article went to press, the parties will need to account for the unique purposes of private law, as opposed to judicial review. As discussed below, the courts may be hesitant to find that the Minister of Foreign Affairs acted maliciously (as is required to succeed in the misfeasance tort) when he was making decisions in the purported interests of national security.

\section{The Primary Elements of the Tort}

Before turning to its broader constitutional implications, it is necessary to review the main elements of misfeasance in a public office (malice, unlawful conduct, and material damage) to identify the doctrinal framework in which the debate will be played out. Lord Steyn, in his leading opinion in Three Rivers, explained the rationale for the tort: "[I]n a legal system based on the rule of law executive or administrative power 'may be exercised only for the public good' and not for ulterior and improper purposes." 14 The main point of contention in Three
Rivers was whether the defendants had the requisite malicious state of mind. As with all torts requiring proof of malice, there has been some debate about how to define malice in misfeasance cases.

The leading historical cases on misfeasance tend to involve some degree of bias or personal ill-will toward the plaintiff, and this has come to be known as "targeted" malice. For instance, in the well-known case of Roncarelli v. Duplessis, ${ }^{15}$ the defendant Premier of Québec had a deliberate intention to harm the plaintiff restaurateur for his involvement with the Jehovah's Witnesses. He ordered the revocation of the plaintiff's liquor licence in order to cause financial harm to the plaintiff. In other words, the Premier used his influence for the improper purpose of punishing the plaintiff for supporting his coreligionists.

The element of malice is critical because it separates the tort of misfeasance in a public office from mere judicial review. Those whose rights are affected by unlawful administrative action can seek judicial review to have that action set aside or reconsidered. However, they can only claim damages in tort if some sort of bad faith was involved. The malice requirement was historically aimed at protecting public officers who made good-faith errors of judgment. ${ }^{16}$ As long as they were not motivated by spite or some improper purpose, they could not be subject to a claim in tort.

However, the malice requirement is now subject to a more liberal interpretation. In recent years, a second type of malice or "limb" of the tort has evolved: where the public officer knowingly acts unlawfully or in excess of power, with the knowledge that the plaintiff will probably be harmed by that unlawful action. The impugned actions need not be targeted toward the plaintiff, as long as the plaintiff is within the class of persons who will probably be harmed. ${ }^{17}$ In Three Rivers, Lord Steyn defined the degree of knowledge required to satisfy the second limb of the tort as either actual knowledge or subjective recklessness, with respect to both the lawfulness of the officer's actions and their likelihood to cause harm to the plaintiff. ${ }^{18}$ Recklessness is considered to be bad faith be- 
cause the officer proceeds in the absence of an honest belief in the lawfulness of his actions.

Obviously, the second limb of the tort can involve conduct that is much less "abusive" or "malicious" in the way that those terms are normally understood. The defendant need not have acted for an ulterior motive. Rather, because the defendant did not have an honest belief in the lawfulness of her actions, we presume that she was acting for reasons other than the public good. The recognition of this second limb has the potential to significantly expand the scope of liability for misfeasance in a public office. While instances of a public officer acting with express ill-will toward a plaintiff are rare, instances of mere subjective recklessness are presumably more frequent. ${ }^{19}$

The reasoning in Three Rivers was adopted by the Supreme Court of Canada in Odhavji Estate, which provided further guidance on the type of misconduct that could form the basis of a misfeasance claim. Odhavji Estate was a claim against several police officers who had been involved in the shooting of a robbery suspect, and who allegedly failed to comply with the ensuing internal investigation. This was a breach of their duties under the Ontario Police Services Act. ${ }^{20}$ Justice Iacobucci, for the Court, concluded that breach of statutory duty, and not just abuse of power, was capable of supporting a claim in misfeasance. In the course of his opinion, Justice Iacobucci wrote that the tort could be grounded in "a broad range of misconduct," and that the essential question is "whether the alleged misconduct is deliberate and unlawful." ${ }^{21}$ Like the broad definition of malice, the conclusion that any unlawful conduct can form the basis of a misfeasance claim has the potential to widen the scope of recovery.

Interestingly, both the Supreme Court's and the Ontario Court of Appeal's ${ }^{22}$ decisions in Odhavji Estate made reference to, and apparently accepted (albeit indirectly), the potential for liability in misfeasance for the unlawful exercise of a prerogative power. For instance, in finding that the tort could be based on the breach of a statutory duty, Justice Iacobucci wrote that misfeasance "is not limited to circumstances in which the defendant officer is engaged in the unlawful exercise of a particular statutory or prerogative power." ${ }^{23}$ However, neither court cited any case actually involving the exercise of a prerogative power, and the language appears to have been used somewhat offhandedly (elsewhere in their respective judgments, the courts referred simply to "legislative and administrative powers"). Thus, it is not clear that the references to prerogative powers in Odhavji Estate, which were obiter dicta in any event, will have much bearing on the Abdelrazik litigation.

The other main element of misfeasance in a public office is material damage, as affirmed by the House of Lords in Watkins v. Home Office. ${ }^{24}$ That case is particularly pertinent here because it involved an allegation that the defendants had infringed the plaintiff's constitutional rights, specifically a prisoner's right to private correspondence with his legal advisors. The English Court of Appeal had allowed the claim, concluding that breach of constitutional rights represented an independent form of misfeasance in a public office, which was actionable per se. The House of Lords overturned this decision. Apart from the difficulties posed by defining constitutional rights in a country, like England, with no codified constitution, Lord Bingham explained that "the primary role of the law of tort is to provide monetary compensation for those who have suffered material damage rather than to vindicate the rights of those who have not." ${ }^{25} \mathrm{He}$ acknowledged that there was a public interest in holding public servants accountable for their conduct, but suggested that those who have not suffered material damage must seek alternative redress, whether through judicial review or disciplinary proceedings against the relevant officers.

This divergence in the purposes of judicial review and tort law will likely be key to Abdelrazik's civil claim. Justice Zinn has already reviewed the denial of an emergency passport from an administrative or constitutional law perspective: Abdelrazik successfully argued that the minister had not properly justified his decision and that it should be reversed. In Lord Bingham's words, Abdelrazik's rights have been vindicated. However, the purpose of the civil claim is to obtain damages to compensate $\mathrm{Ab}$ - 
delrazik for the harm that he has suffered and, possibly, to punish the minister for his highhanded or abusive conduct. In order to award damages in tort, a court will have to conclude that the minister's exercise of prerogative power was malicious (in either its targeted or reckless form). And although the element of malice has been watered down in recent years, it is still there to protect public officials who make legitimate errors of judgment. In our security-conscious era, a court may be unwilling to conclude that the minister was acting for an improper purpose.

\section{Application to Abdelrazik's Case}

Abdelrazik's misfeasance claim against the Minister of Foreign Affairs is still in its early stages, so it would be foolish to predict its possible success or failure. I present here only some preliminary thoughts about the application of the various elements of the tort to his case.

Given the Supreme Court's statement in Odhavji Estate that misfeasance in a public office can be based on any unlawful conduct, this element of the tort should pose little difficulty for Abdelrazik. As indicated in my introduction, Abdelrazik's misfeasance claim is based on the minister's refusal to issue him an emergency passport after he had booked and paid for a flight home in April 2009. In Abdelrazik's Charter application, Justice Zinn found that this refusal was a breach of his right under section 6(1) of the Charter to enter and remain in Canada. He rejected the government's argument that section 6(1) merely prevents the government from refusing entry to Canada and does not impose a positive obligation to issue a passport. Justice Zinn found that such an interpretation would render the rights under section 6(1) illusory, quoting from the Federal Court of Appeal's decision in Kamel v. Canada (Attorney-General):

To determine that the refusal to issue a passport to a Canadian citizen does not infringe that citizen's right to enter or leave Canada would be to interpret the Charter in an unreal world.... The fact that there is almost nowhere a Canadian citizen can go without a passport and that there is almost nowhere from which he or she can re-enter Canada without a passport are, on their face, restrictions on a Canadian citizen's right to enter or leave Canada, which is, of course, sufficient to engage Charter protection. Subsection 6(1) establishes a concrete right that must be assessed in the light of present-day political reality. ${ }^{26}$

Further, since the government had not adduced any evidence as to why the refusal to issue an emergency passport was justified in the circumstances, Justice Zinn found that the breach of Abdelrazik's rights under section 6(1) was not saved under section 1 of the Charter. This unjustified breach of Charter rights should suffice as "unlawful" conduct for the purposes of a claim for misfeasance in a public office.

Even beyond the breach of his Charter rights, Abdelrazik could point to the lack of procedural fairness as evidence of the government's unlawful conduct. Abdelrazik's emergency passport was purportedly refused under section 10.1 of the Canadian Passport Order ${ }^{27}$ as being necessary for the national security of Canada. ${ }^{28}$ Justice Zinn criticized the minister for invoking section 10.1 without any further explanation. The minister did not apparently seek input from Passport Canada and did not specify the information on which the determination regarding national security had been made. ${ }^{29}$

The failure to meet standards of procedural fairness can support a claim for misfeasance in a public office, independent of any other breach of rights. For instance, in O'Dwyer v. Ontario (Racing Commission), ${ }^{30}$ the Commission denied the plaintiff's right to a hearing after his status as a thoroughbred racing official was effectively revoked. The Ontario Court of Appeal found that this amounted to misfeasance. Similarly, the minister's failure to explain or follow any apparent procedures to justify the refusal to issue an emergency passport to Abdelrazik should also satisfy the requirement that the minister acted unlawfully.

Perhaps the more difficult hurdle for Abdelrazik to overcome will be the element of malice. As it stands, there is little direct evidence of the minister's state of mind when deciding to refuse the emergency passport. All the same, while Justice Zinn acknowledged that bad faith was 
not a requirement for his finding that Abdelrazik's section 6(1) rights had been infringed, he stated that he would have had "no hesitation" in finding bad faith, had it been necessary. ${ }^{31} \mathrm{He}$ explained:

[T]he Minister waited until the very last minute before the flight was to depart to deny the emergency passport, and although the basis of the refusal is indicated, he provides no explanation of the basis on which that determination was reached, no explanation as to what had changed while Mr. Abdelrazik resided in the Canadian embassy that warranted this sudden finding, and nothing to indicate whether the decision was based on him being a danger to the national security of Canada or on being a danger to another country. Further, there was no explanation offered as to whether Mr. Abdelrazik posed a security risk if returned to Canada, or a greater security risk, than he did in Sudan. ${ }^{32}$

At the very least, the minister's actions should satisfy the second limb of the misfeasance tort, which requires that the defendant be subjectively reckless as to the lawfulness of his actions, and that he foresee that the plaintiff will probably be harmed. The minister knew about section 10.1 of the Canadian Passport Order, and it seems safe to assume that he knew, or was at least reckless to the fact, that the denial of a passport under that section requires justification. It can also be safely assumed that the minister knew that Abdelrazik would be harmed by the denial of an emergency passport: without the passport, Abdelrazik would remain exiled and living in the Canadian Embassy in Sudan.

The final main element of misfeasance in a public office, material damage, should not be especially problematic for Abdelrazik. Because the minister failed to issue him an emergency passport, he was stranded in Sudan and suffered at least some physical and psychological harm. He also incurred financial loss in booking a flight that he was not allowed to board. If proven, these harms should qualify as material damage.

On preliminary analysis, then, Abdelrazik has an arguable claim for misfeasance. Nevertheless, given the context of national security and suspected terrorism, the courts may be hesitant to award damages against the minister, particularly since the refusal to issue a passport is a prerogative power. The decision was within the minister's discretion and was made expressly, though perhaps too sketchily, for the purposes of national security. Moreover, even though they were never substantiated, the allegations that Abdelrazik was engaged in terrorist activity will linger in the public consciousness. Should a court award damages to Abdelrazik for the minister's public misfeasance, it can expect at least some public and critical backlash.

\section{Judicial Review of Prerogative Powers}

Misfeasance in a public office is closely linked with the process of judicial review. Importantly, if the conduct in question is entitled to judicial deference, the possibility of a claim in tort is dubious. Therefore, to predict the outcome of Abdelrazik's misfeasance claim, it is instructive to examine the degree of deference afforded to the prerogative power to deny a passport, particularly in the interests of national security.

While the exercise of prerogative powers was historically insulated from review by the courts, this is no longer the case. In Council of Civil Service Unions v. Minister for the Civil Service, ${ }^{33}$ the House of Lords affirmed that judicial review is available for many aspects of the prerogative. Lord Scarman explained that, in modern law, "the controlling factor in determining whether the exercise of prerogative power is subject to judicial review is not its source but its subject matter." 34 Thus, while matters like entering treaties, declaring war, and conducting foreign policy are not justiciable, matters that have the effect of altering a person's rights or obligations, or depriving him of certain advantages or benefits, are amenable to review by the courts. ${ }^{35}$ The issuance and revocation of passports falls into this latter category. ${ }^{36}$ In $R$. v. Secretary of State for Foreign and Commonwealth Affairs, ex parte Everett, ${ }^{37}$ Lord Justice O'Connor described the prerogative power over passports as "an area where commonsense tells one that, if for some 
reason a passport is wrongly refused for a bad reason, the court should be able to inquire into it." ${ }^{38}$ The English Court of Appeal further held in Everett that procedural fairness must be observed when exercising the prerogative regarding passports. Accordingly, Abdelrazik's claim against the Minister of Foreign Affairs should not be struck out on the simple grounds that it involves the exercise of a prerogative power.

The matter is complicated, however, by the minister's invocation of national security as the reason for denying Abdelrazik an emergency passport. While the courts have been willing to review the minister's discretion regarding passports, they have shown a special degree of deference when it comes to matters of national security. This deference was thoroughly expounded by the House of Lords in Secretary of State for the Home Department v. Rehman, ${ }^{39}$ a case which involved a deportation order based on Mr. Rehman's suspected links to terrorist groups. Lord Hoffmann, in particular, explained how questions of national security require deference in light of the separation of powers:

[T] he question of whether something is "in the interests" of national security is not a question of law. It is a matter of judgment and policy. Under the constitution of the United Kingdom and most other countries, decisions as to whether something is or is not in the interests of national security are not a matter for judicial decision. They are entrusted to the executive. ${ }^{40}$

Lord Hoffmann reasoned that determinations of national security involve a balancing of many factors, including the extent of future risk. This is an inherently imprecise evaluation, which is entitled to considerable deference. Further, after the attack on the World Trade Center, which occurred while Rehman was still under reserve, Lord Hoffmann appended a foreboding admonition to his decision:

[I]n matters of national security, the cost of failure can be high. This seems to me to underline the need for the judicial arm of government to respect the decisions of ministers of the Crown on the question of whether support for terrorist activities in a foreign country constitutes a threat to national security. It is not only that the executive has access to special in- formation and expertise in these matters. It is also that such decisions, with serious potential results for the community, require a legitimacy which can be conferred only by entrusting them to persons responsible to the community through the democratic process. ${ }^{41}$

Thus, given the gravity of the security concerns in the post-9/11 world, the courts may be expected to give wider berth to executive decisions involving questions of national security.

It is not entirely clear whether Canadian courts will follow England's lead on this issue. In perhaps the most famous Canadian case involving the government's obligations toward a citizen suspected of terrorism, Khadr v. Canada (Prime Minister), ${ }^{42}$ Justice O'Reilly held that prerogative decisions relating to foreign affairs, while generally falling to the executive, could be subject to Charter scrutiny where they affected the rights of an individual. ${ }^{43}$ Ultimately, Justice O'Reilly ordered that the government request the repatriation of Khadr, who has been held at Guantanamo Bay since 2002. This order was upheld by the Federal Court of Appeal, but not by the Supreme Court of Canada. While the Supreme Court affirmed that the prerogative power over foreign affairs was subject to judicial review, it held that the appropriate remedy was limited to declaratory relief. ${ }^{44}$

The words of Justice Nadon, who dissented at the Federal Court of Appeal, are instructive in this regard:

Why Canada has [not requested Khadr's repatriation] is, in my respectful view, not for us to criticize or inquire into. Whether Canada should seek Mr. Khadr's repatriation at the present is a matter best left to the Executive. In other words, how Canada should conduct its foreign affairs, including the management of its relationship with the US and the determination of the means by which it should advance its position in regard to the protection of Canada's national interest and its fight against terrorism, should be left to the judgment of those who have been entrusted by the democratic process to manage these matters on behalf of the Canadian people. ${ }^{45}$

While it is too early to know the full effects of the Supreme Court's decision in Khadr, it will 
presumably influence the future scope of review for matters of prerogative involving foreign policy, such as the Abdelrazik litigation.

Similar issues arise with respect to the prerogative power to issue or deny passports. In the recent Federal Court of Appeal decision in Kamel, the court held that decisions regarding national security, even in the issuance of passports, ought to be treated with humility and deference. ${ }^{46}$ If the Minister of Foreign Affairs decided that the denial of a passport was necessary for the purposes of national security, then "it is not for the court to speculate" on whether the passport applicant actually presents a risk of harm to the national or international community. ${ }^{47}$ Further, the court may have to be satisfied with the "hypotheses and realistic speculations" of the public officials involved. ${ }^{48}$

At the same time, the court in Kamel stressed the need for judicial vigilance, "since this is an area in which information is rare and secret and where there is a temptation to overreact, even in good faith." ${ }^{49}$ Accordingly, courts may still take a sceptical stance when presented with an executive decision that was purportedly made in the interests of national security. The court noted in Kamel that the minister's discretion in denying passports must be exercised in a reasonable manner, taking relevant factors into account. In addition, the phrase, "is necessary for the national security of Canada or any other country" provided, in the court's view, a framework for legal debate" [emphasis added]. ${ }^{50}$ The minister must believe that the denial of a passport is necessary, not simply advantageous or convenient.

In Abdelrazik's Charter claim, Justice Zinn found that the minister had not sufficiently justified that the denial of an emergency passport was necessary for national security. Indeed, the minister had not provided any justification at all. Justice Zinn quipped that the minister was not entitled to simply say, "Trust me," when making a decision that infringed Abdelrazik's Charter rights. He explained:

While it is not the function of the judiciary to second guess or to substitute its opinion for that of the Minister, when no basis is provided for the opinion, the Court cannot find that the refusal was required and justified given the significant breach of the Charter that refusing a passport to a Canadian citizen entails. ${ }^{51}$

So, in terms of judicial review, the courts seem to demand at least some justification for the denial of a passport, even in cases involving national security.

Whether this level of scrutiny will extend to a tort claim, however, is unclear. While judicial review and the misfeasance tort have overlapping purposes, they are not coextensive. Imposing damages in tort amounts to concluding that a public officer has abused his powers. It is not a question of simple procedural irregularity, but of acting with malice or an improper purpose. In Abdelrazik's case, the court may be unwilling to conclude that the minister acted with an improper purpose when he denied the emergency passport on the grounds of national security. When he lived in Montreal, Abdelrazik was acquainted with known terrorists. He was, rightly or wrongly, listed by the United Nations 1267 Committee as an associate of Al-Qaida. Accordingly, although Abdelrazik was never convicted of any offence, it was not unreasonable for the minister to be on his guard. The decision to deny him an emergency passport seems to have been made in the legitimate interests of national security. Whether Abdelrazik should have been provided with more information or explanation for the minister's decision is a matter for administrative law. But whether it was made for a malicious or improper purpose the question asked by the law of tort - may yield a different answer.

\section{The Misfeasance Tort and Accountability}

Misfeasance in a public office is a tort that is currently on the upswing. Although it often captures conduct that could just as easily be framed as negligence or another tort, misfeasance seems to provide a level of psychological vindication to plaintiffs that those other torts do not. A claim in misfeasance paints the public officer's conduct as abusive and malicious, and allows the plaintiff to hold the defendant liable for 
the way she has misused the powers entrusted to her. This was the plaintiff's motive in McMaster $v$. Canada $a^{52}$ a recent and rather atypical case in which a federal prisoner brought a successful misfeasance claim against prison authorities for repeatedly denying him properly-fitting shoes. ${ }^{53}$ The claim could well have been framed in negligence. However, the plaintiff's lawyer stressed the role of the misfeasance tort in holding government officials accountable:

\begin{abstract}
If we run into situations where people at city hall, or people in the provincial government, or people of the federal government start abusing our rights, or not seeing that we are properly served, [the tort of misfeasance in a public office] is something that the average citizen can use to effect some sort of remedy. ${ }^{54}$
\end{abstract}

Misfeasance in a public office is thus poised to become a critical tool in the promotion of government accountability. While administrative procedures may allow claimants to have the decisions against them reconsidered, only the misfeasance tort can provide public denunciation of the official's conduct as abusive and impose damages against the official as a sort of penalty. ${ }^{55}$ Misfeasance is being claimed for increasingly varied types of official misconduct, including not just abuse of powers, but also breach of statutory duty and failure to observe procedural fairness. With the Abdelrazik claim, misuse of prerogative powers may well be added to that list. Given that the exercise of many prerogative powers is already subject to judicial review, their susceptibility to misfeasance claims seems to be the next logical step.

Nevertheless, questions of national security will likely receive a higher degree of deference than the licensing or zoning decisions that are the typical subject matter of misfeasance claims. While not a guarantee of immunity from scrutiny, the invocation of national security may provide a buffer into which the private-law courts are hesitant to intrude. When the courts have previously examined national security, it has generally been in the context of administrative review or constitutional claims. A finding against the relevant public official usually means only that a decision will need to be reconsidered or reversed. By contrast, a successful misfeasance claim will mean that the public official is liable to pay damages and will be branded as having abused her powers. Whether the courts will be willing to evaluate and sanction decisions involving national security for these private law purposes remains an open question.

Thus, while the courts are likely to find that prerogative powers are technically justiciable, even for private law purposes, there may still be effective immunity in tort law for the discretionary exercise of those powers in the interests of national security. Given the concern for the separation of powers already expressed by the English and Canadian courts, it is unclear whether they would impose damages in misfeasance claims involving issues of national security, unless the defendant's conduct were clearly abusive. Whatever the result, Abdelrazik's civil claim provides an opportunity to debate the role of misfeasance in a public office in a highprofile and impassioned set of circumstances. Any judicial decision will need to grapple with the underlying purposes of tort law and its role in the supervision of public administration. It is a decision that both tort law and constitutional specialists can eagerly await.

\section{Notes}

* $\quad$ Assistant Professor, Faculty of Law, University of Western Ontario. Part of the research for this comment was funded by a Standard Research Grant from the Social Sciences and Humanities Research Council, which the author holds jointly with François Larocque from the University of Ottawa.

1 Abdelrazik v. Canada (Foreign Affairs), 2009 FC 580, 346 F.T.R. 186 (CanLII) [Abdelrazik].

2 Abdelrazik v. Canada (A.G.) (September 21, 2009), Ottawa T-1580-09 (F.C.) (Statement of Claim), online: Canadian Centre for International Justice <http://www.ccij.ca/programs/cases/ index.php?WEBYEP_DI=11\#Abdelrazik $>$.

3 Part I of the Constitution Act, 1982, being Schedule B to the Canada Act 1982 (U.K.), 1982, c. 11.

4 For further discussion on the history of the tort, see R.C. Evans, "Damages for Unlawful Administrative Action: The Remedy for Misfeasance in Public Office" (1982) 31 International and Comparative Law Quarterly 640.

5 (1703) 2 Lord Raymond 938 at 954 (K.B.), 92 E.R. 
126, rev'd (1706), 3 Lord Raymond 320 (H.L.), 92

E.R. 710.

6 [2000] UKHL 33, [2000] 2 W.L.R. 1220 (BAILII) [Three Rivers].

72003 SCC 69, [2003] 3 S.C.R. 263 (CanLII)

[Odhavji Estate].

8 See Erika Chamberlain, "What is the Role of Misfeasance in a Public Office in Modern Canadian

Tort Law?" Canadian Bar Review (forthcoming).

9 See, e.g., Miguna v. Toronto Police Services Board, 2008 ONCA 799, 301 D.L.R. (4th) 540 (CanLII); McNutt v. A.G. Canada et al., 2004 BCSC 1113, 133 A.C.W.S. (3d) 49 (CanLII).

10 See, e.g., Ontario Racing Commission v. O'Dwyer, 2008 ONCA 446, 293 D.L.R. (4th) 559 (CanLII) [O'Dwyer]; Genesis Land Development Corp. v. Alberta, 2009 ABQB 221, 96 L.C.R. 239 (CanLII).

11 Misfeasance in a public office is also included in the civil claim by Suadd Hagi Mohamud, who was stranded in Kenya for nearly three months when her Canadian passport was voided by the High Commission in Nairobi following allegations that she was an "impostor." See Tu Thanh Ha, "Woman stranded in Kenya sues Ottawa for \$2.5-million" The Globe and Mail (21 August 2009). However, that case does not involve the allegations of torture or terrorism that make the Abdelrazik case such a political tempest.

12 Peter W. Hogg, Constitutional Law of Canada, 5th ed. (Scarborough: Thomson Canada, 2007) at $1-20$.

132010 SCC 3 (CanLII) [Khadr].

14 Three Rivers, supra note 6 at 1230, quoting Jones $v$. Swansea City Council (1989), [1990] 1 W.L.R. 54 at 85 (C.A.) (Lord Justice Nourse).

151959 CanLII 50, [1959] S.C.R. 121.

16 See Harman v. Tappenden (1801), 1 East 555, 102 E.R. 214 (K.B.), where the plaintiff successfully obtained mandamus after being wrongfully denied the office of freeman in his local company of free fishermen and dredgermen, but could not claim damages for his lost profits because the defendants had not been motivated by malice.

17 See, e.g., Bourgoin v. Ministry of Agriculture, Fisheries and Food (1985), [1986] Q.B. 716 (C.A.), where the plaintiffs were French turkey producers unlawfully excluded from the English market during the lucrative Christmas season. The defendant had revoked their turkey importing licences for the purpose of protecting the English turkey industry from competition.

18 Three Rivers, supra note 6 at 1231-1233.

19 For a critique of the way the malice requirement has been weakened in recent years, see Erika Chamberlain, "The Need for a 'Standing' Rule in
Misfeasance in a Public Office" (2007) 7 Oxford University Commonwealth Law Journal 215.
20

21

22

(O)
(ON C.A.), (2000) 52 O.R. (3d) 181. The majority of the Court of Appeal struck out the misfeasance claim against the police officers because it concluded that the tort was limited to abuses of administrative or prerogative powers, and did not encompass mere breach of statutory duty.

23 Odhavji Estate, supra note 7 at para. 17 (emphasis added).

24 [2006] UKHL 17, [2006] 2 A.C. 395 (BAILII), rev'g [2004] EWCA Civ. 966, [2005] 2 W.L.R. 1538 (BAILII).

25 Ibid. at para. 9.

262009 FCA 21, 388 N.R. 4 (CanLII) at para. 15 [Kamel]. The case involved the refusal to issue a passport to a citizen who wanted to leave the country, rather than one who wanted to return.

27 S.I./81-86.

28 Abdelrazik, supra note 1 at para. 130.

29 Ibid. at para. 155.

30 O'Dwyer, supra note 10.

31 Abdelrazik, supra note 1 at para. 153.

32 Ibid.

33 [1983] UKHL 6, [1985] A.C. 374 (BAILII).

34 Ibid. at 13 (BAILII).

35 Ibid. at 15 (BAILII) (Lord Diplock).

36 See Kamel, supra note 26.

37 [1988] EWCA Civ 7, [1989] 2 W.L.R. 224 (BAILII) [Everett].

38 Ibid. at 224.

39 [2001] UKHL 47, [2003] 1 A.C. 153 (BAILII).

40 Ibid. at para. 50.

41 Ibid. at para. 62.

422009 FC 405, 341 F.T.R. 300 (CanLII), aff'd 2009 FCA 246, 310 D.L.R. (4th) 462 (CanLII), aff'd in part 2010 SCC 3 (CanLII).

432009 FC 405 at paras. 40-41.

44 Khadr, supra note 13 at para. 39.

45 Canada (Prime Minister) v. Khadr, 2009 FCA 246, 310 D.L.R. (4th) 462 (CanLII) at para.106.

46 Kamel, supra note 26 at para. 48.

47 Ibid. at para. 67.

48 Ibid.

49 Ibid. at para. 48.

50 Ibid. at paras. 29-30.

51 Abdelrazik, supra note 1 at para. 155.

522008 FC 1158, 336 F.T.R. 92 (CanLII), aff'd 2009 FC 937 (CanLII).

53 For a more detailed discussion, see Chamberlain, supra note 8.

54 Quoted in Cristin Schmitz, "Serial killer gets 
\$6,000 for pain and suffering" Lawyer's Weekly (7 November 2008).

55 Even an award of damages under section 24(1) of the Charter does not seem to provide the same level of vindication as a claim in misfeasance. As Justice Zinn pointed out, such a finding does not entail a conclusion that the Minister of Foreign Affairs acted in bad faith: Charter rights can be breached without any intention on the defendant's part to harm the claimant: Abdelrazik, supra note 1 at para. 65 . 